\title{
Role of strategic management for employee engagement and skill development for start-ups
}

\author{
Praveen Kulkarni
}

Department of MBA, KLS, Gogte Institute of Technology, Udyambag, Belagavi, India

Rohit Mutkekar

Goa Institute of Management, Poriem, Sattari, India, and

Sanjeev Ingalagi

Department of MBA, KLS, Gogte Institute of Technology, Udyambag, Belagavi, India

\begin{abstract}
Purpose - Start-ups are the new avenues for innovation and employment. Strategic management is critical for employee engagement and skill development of start-ups. This study aims to understand the impact of strategic management on employee engagement and skill development.

Design/methodology/approach - The study attempts to identify principal factors of strategic management influencing employee engagement and skill development. Structural equation modeling has been used to understand effects of the study.

Findings - The study results have shown the challenges concerning employee skill development and reflected on importance of the employee engagement programmes for the growth of the human resource in the start-ups.

Research limitations/implications - The study has confined to strategic management for employee engagement and skill development. However, studies related to challenges encountered by start-ups in the specific areas of marketing, operations and finance, etc. would provide more detailed impact on the growth of start-ups.

Practical implications - This study provides an insight into strategic management for employee engagement and skill development. The results would provide directions for improving strategy management from the perspective of employee engagement and skill development.

Social implications - The study on start-ups provides a direction to the owners of start-ups to understand the importance of strategic management and human resource management for building strong enterprising which can provide employment opportunity for the youth of the nation and improve the society at large.

Originality/value - This paper is an attempt to provide directions for managing challenges from the perspective of employees' engagement and skill development, which is essential for growth and sustainability in the future.
\end{abstract}

Keywords Start-ups, Strategic management, Skill development, Employee engagement, Start-ups

Paper type Research paper

(C) Praveen Kulkarni, Rohit Mutkekar and Sanjeev Ingalagi. Published in Vilakshan - XIMB Journal of Management. Published by Emerald Publishing Limited. This article is published under the Creative Commons Attribution (CC BY 4.0) licence. Anyone may reproduce, distribute, translate and create derivative works of this article (for both commercial and non-commercial purposes), subject to full attribution to the original publication and authors. The full terms of this licence may be seen at http:// creativecommons.org/licences/by/4.0/legalcode

Received 19 July 2020 Revised 24 August 2020 27 August 2020 Accepted 28 August 2020

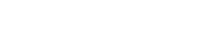

Role of

strategic

management 
$\mathrm{XJM}$

$17,1 / 2$

\section{Introduction}

Ever since the inception of start-ups, youth has received a platform for innovation and employment opportunity (Salamzadeh and Kawamorita Kesim, 2017). Therefore, start-ups have created a niche for themselves in the industry for innovation and product development (Giardino et al., 2015).

Start-up India flagship programme floated by the Government of India has also provided an opportunity for Indian youth to establish start-ups.

The impact of Start-up India has observed substantial growth in the establishment of start-ups in India. A similar trend in the establishment of start-ups is also witnessed across the world (Berger, 2016; Frederiksen et al., 2017; Georgallis, 2017).

Growth and development of start-ups are influenced by the experience of founders and their managerial skill sets. (Zaheer et al., 2019). Hence, the application of management theories related to process, people and proposition is essential for start-ups (Kohler, 2016).

The success of a start-up depends upon the experience of founders and holistic dimensions of the product, finance, market and human resource (Klotins et al., 2016). The initial stage for any start-up is usually influenced by the founder's experience. However, for long-term sustainability, strategic management and human resource management are critical for any start-up (Newbery, 2018).

Strategic management and human resource management provide support to start-ups to sustain growth during an unpredictable business environment. (Bratianu, 2017). Therefore, developing an effective strategy is essential for creating a sustainable work environment which would further boost growth of start-ups (Bendickson et al., 2017).

Practices of human resource management would provide directions to employees to operate in a high-risk business environment and provide a platform to learn and manage risk while achieving organizational goals (Hasan et al., 2017).

One of the key human resource practices for growth of the start-ups is skill set of employees (Rabideau et al., 2016). Skill sets of employees are developed through effective employee engagement programmes (Kaur and Sharma, 2019). Therefore, it is important to understand the role of strategic management in developing skill sets through effective employee engagement programmes (Beynon,2016).

Hence, this study has been undertaken to understand the role of strategic management for effective employee engagement and skill development of employees.

\section{Role of strategic management and its impact on employee engagement and skill development of start-ups}

In this section, the study provides definitions and concepts related to strategic management and its impact on employee engagement and skill development.

Start-ups: They are the institutions designed to create new products and services under the situation of uncertainty. According to Edison (2015), start-ups are the organization that creates high-tech innovative products without having past operational experiences having done so.

Strategic management: Strategic management concept was first introduced in the early 1960s. Strategic management includes planning an approach for implementation of strategic plans for the corporates. According to Mintzberg (1994), strategic management involves strategic thinking, which is based on intuition and creates open space for new ideas. This definition elaborates that strategic management is a befitting concept for the growth of start-ups. 

develop these strategies based on vision and mission of the organization. Strategy formulation in start-ups has a potent influence on the founder's vision on the start-up (Kohtamäki, 2012). Hence, strategic management is essential for the success of start-ups in respective business domain. Start-ups operate in a dynamic business environment; therefore, strategic management acts as an effective tool for start-ups for decision-making, monitoring, planning pragmatic policies, procedures and managing technology (Talaulicar, 2005; Rey and Bastons, 2018; Afolayan et al.,2015; White et al.,2015).

Start-ups need to develop a strategy of collaboration. That is essential for developing an innovative mindset of employees. This is imperative for the success of start-ups (Zahra and Nambisan, 2012).

Strategic management is long-term planning tool to create strength and competitive advantage for the organization (Allio, 2006). Thus, provides the right direction for managing competition for organization and builds self-efficacy amongst the founders of start-ups (Tunstall, 2009). These studies conclude that startup's strategic management is influenced by the role of top management, vision, and mission, strategic objectives, policies and technology.

\section{Employee engagement and skill development for employee of start-ups}

Start-ups operate in a dynamic business environment (Forster et al., 2013; Baptista et al., 2014). Managing human resources with an employee engagement programme would be useful, as it involves employee's physical, cognitive and emotional involvement. Therefore, employee engagement is essential for attracting and retaining a talented workforce (Moser et al., 2017; Girotra and Kaushik, 2018).

Employee engagement programmes include training and development, compensation and creating organization brand value (Anitha, 2014; Coad et al., 2016; Bicho et al., 2019). Start-ups training programmes on employee engagement need to be focused on developing skill sets related to flexibility, innovation capacity building and communication (Forster et al., 2013; YuBo, 2014).

The aim of employee engagement and skill development is to create a high-performance work system and to manage talented workforce of start-ups (Bendickson et al., 2017). Therefore, training employees is a necessary aspect for start-ups (Bendickson et al., 2017).

Hence, from the above studies, it can be emphasized that employee engagement is an essential factor for the motivation of employees and developing skill sets for the growth of the start-ups.

The above literature review shows that strategic management direction, employee engagement and skill development influence the growth of start-ups. The review was focused upon strategic management, employee engagement or skill development separately. However, there is a need to have holistic amalgamation of strategic management, employee engagement and skill development from the perspective of start-ups. In the next section, conceptualization of the theoretical foundation for the research model is conducted.

\section{Antecedents of strategic management and its interrelationship with employee engagement and skill development}

The literature review lays a strong foundation for important variables of strategic management, employee engagement and skill development in start-ups. The variables accepted for the study is based on the literature review and are listed as follows: vision and 
$\mathrm{XJM}$

$17,1 / 2$

mission statement, strategic objectives, accountability and responsibility, employee engagement and skill development.

Importance of vision and mission statement for star-ups: Vision and mission statement for the organization is critical in strategic management (Alegre et al., 2018). A mission statement is vital for maintaining a competitive advantage (Rey and Bastons, 2018; MasMachuca, 2017). Therefore, developing a vision and mission statement has a positive impact on the growth of an organization (Stewart et al., 2017).

The above studies mention that vision and mission statements are critical for the growth of an organization. Hence, it is imperative to understand the impact of vision and mission statements on the growth of the start-ups.

Strategic objectives and goals of the organization: According to Biga Diambeidou and Gailly (2011), the role of investors and key decision-makers of a startup is to pay attention to strategy and strategic objectives. Strategic management is influenced by factors such as experience in managing business and market analysis. In a study conducted by Watson et al. (1998) shows that start-ups founders experience has a direct impact on the framing business objectives and matching employee expectation.

Responsibility and accountability: The role of responsibility involves doing the work, whereas accountability involves reporting (Cornock, 2011). The concept of total responsibility management depicts a link between visions, mission with objectives of the organization. Hence, a measurement of responsibility and accountability is critical for success of the organization. (Waddock et al., 2002). The analysis for responsibility and accountability is crucial from perspective of the founders of the organization, as founders responsibility and accountability influence growth of the organization (Ferrell et al., 2011).

Employee engagement: Large organization have been applying the concept of employee engagement to enhance workforce productivity (Weiblen and Chesbrough, 2015). Employee engagements benefits in creating a sense of recognition, trained workforce etc. Employee engagement programmes have to be implemented with caution, as the eco-system of startups differs significantly from large corporate (Weiblen and Chesbrough, 2015; Manning, 2016; Gulyani and Sharma, 2018).

Skill development: The most critical challenge encountered by the start-ups is skill sets of the workforce (Picken, 2017). Indian start-ups are implementing measures to improve the skill sets of the workforces through collaboration with foreign institutes, yet there is an enormous gaps in skill-set development of the workforce (Majumdar et al., 2020). There is a need for creating the right eco-system for start-ups to develop skill sets in changing the economy of business (Agrawal et al., 2017). Therefore, the success of an organization depends on skill sets of the workforce (Kuschel et al., 2018).

The above studies shown in Table 1 summarizes the of summary on strategic thinking and its interrelationship with employee engagement and skill development in start-ups.

\section{Research methodology}

This section of the paper presents the formulation of a hypothesis based on the literature review of model development and research on strategic management, employee engagement and skill development of start-ups. Details of participants for the study, instrument development for the study, data collection methods and measurement methods of data are presented in this section.

\section{Formulation of hypothesis}

The hypotheses are developed based on the literature review on strategic management, employee engagement and skill development in the context of start-ups. The hypotheses 


\begin{tabular}{|c|c|c|c|}
\hline Author, Year & Study variables & Details & $\begin{array}{l}\text { ole of } \\
\text { ateoic }\end{array}$ \\
\hline Stewart et al. (2017) & $\begin{array}{l}\text { Vision and Mission } \\
\text { Statement }\end{array}$ & $\begin{array}{l}\text { It is important to understand the impact of vision and mission } \\
\text { statement on future growth of startups }\end{array}$ & manage \\
\hline Alegre et al. (2018) & $\begin{array}{l}\text { Mission statement of } \\
\text { the organization }\end{array}$ & $\begin{array}{l}\text { Mission statement of the organization provides directions for } \\
\text { developing competitive advantage startups }\end{array}$ & \\
\hline Watson et al. (1998) & $\begin{array}{l}\text { Strategic objectives } \\
\text { for startups }\end{array}$ & $\begin{array}{l}\text { Startup founder's experience of business has an impact on } \\
\text { framing of strategic objectives }\end{array}$ & 83 \\
\hline $\begin{array}{l}\text { Biga Diambeidou } \\
\text { and Gailly (2011) }\end{array}$ & Strategic Objectives & $\begin{array}{l}\text { Startups strategic formulation has an impact on strategic } \\
\text { objectives }\end{array}$ & \\
\hline Ferrell et al. (2011) & $\begin{array}{l}\text { Responsibility and } \\
\text { Accountability }\end{array}$ & $\begin{array}{l}\text { Responsibility and accountability not only confined to } \\
\text { employees but in the scenario of startups even the founders are } \\
\text { equally accountable and responsible for the growth of startups }\end{array}$ & \\
\hline $\begin{array}{l}\text { Weiblen and } \\
\text { Chesbrough (2015) }\end{array}$ & $\begin{array}{l}\text { Employee } \\
\text { Engagement }\end{array}$ & $\begin{array}{l}\text { Startups have to be careful in applying the concept of employee } \\
\text { engagement as the eco-system of startups is significantly }\end{array}$ & $\begin{array}{l}\text { Summary } \\
\text { strategic thinkil }\end{array}$ \\
\hline $\begin{array}{l}\text { Picken (2017); } \\
\text { Kuschel et al. (2018) }\end{array}$ & & $\begin{array}{l}\text { The most critical factor for success of a startup depends on the } \\
\text { skill sets of the workforce }\end{array}$ & $\begin{array}{r}\text { and interrelationship } \\
\text { with employee }\end{array}$ \\
\hline $\begin{array}{l}\text { Majumdar et al. } \\
(2020\end{array}$ & Skill development & $\begin{array}{l}\text { The study identified that there is a huge gap in skill sets } \\
\text { required by startups and available with the workforce }\end{array}$ & $\begin{array}{r}\text { engagement and skill } \\
\text { development }\end{array}$ \\
\hline
\end{tabular}

cover following areas, namely, vision and mission statement and its relationship between strategic objectives of start-ups; role of strategic objectives on accountability and responsibility of employees; influence of accountability and responsibility on employee engagement; relationship between employee engagement on skill development and role of skill development in achievement of start-ups vision and mission statement.

Vision and mission of an organization is the crucial factor for the growth and development of the industry (Yadav and Sehgal, 2019). This factor also holds good for startups. Authors note a dearth in research on the relationship between growth of start-ups with vision and mission statement (Watson et al., 1998; Barringer et al., 2005; Patel and Mehta, 2016). Vision and mission statement of the organization is strongly related to strategic objectives of the firm. Hence, start-up's vision and mission statement needs to be understood by the perspective of strategic objectives (Sasaki et al., 2020). Hence, the following hypothesis is formulated as below:

H1. There exists a relationship between vision and mission statement of start-ups with strategic objectives of start-up.

Start-ups enter the market with innovative products and services. Strategic objectives guide in developing job descriptions (Cascio and Graham, 2016), which support development of accountability and responsibility toward each employee working in the start-up (Talaulicar, 2005). Therefore, it is essential to understand the role of accountability and responsibility achieved through strategic objectives of startup. Hence, the following hypothesis is formulated as below:

H2. There exists a relationship between strategic objectives with accountability and responsibility of employees in a start-up.

Accountability and responsibility are the most critical factors in achieving organizational goals. Accountability and responsibility support the employee with role clarity for effective engagement of employees on the job (Grossman and Burke-Smalley, 2018; Davila et al., 2010; 
$\mathrm{XJM}$

$17,1 / 2$

Kohtamäki, 2012). Hence, the role of accountability and responsibility is critical for developing effective employee engagement programmes in the start-ups (Jiang and Luo, 2018). Therefore, a detail study on the role of accountability and responsibility on employee engagement programs needs direction of evaluation for the growth of start-ups. Hence, the following hypothesis is formulated as below:

H3. There exists a relationship between accountability and responsibility with employee engagement in a start-up.

Employee engagement is important for enhancing the efficiency of the employees. Organizations are applying various methods and tools to improve employee engagement. However, the impact of employee engagement programs needs to be evaluated in the perspective of start-ups (Oliveira et al., 2019; Moquin et al., 2019). Employee engagement programs are related to skill development in which right skill sets enhances employee efficiency (Lee et al., 2019). Therefore, a study on employee engagement programs on skill development of employees in start-ups will provide a direction in understanding the effectiveness of employee engagement programmes. Hence, the following hypothesis is formulated as below:

H4. There exists a relationship between employee engagement and skill development of employees in a start-up.

Skill sets of employees are essential for the effective performance of employees. Training and development are interventions for skill development of employees to achieve organization goals. Training programs on skill development needs to match with the vision and mission of start-ups. Hence, a study is required to understand the influence of skill set training on vision and mission achievement of start-ups (Jones et al., 2013; Felce et al., 2016; Dixit, 2018). Hence, the following hypothesis is formulated as below:

H5. There exists a relationship between skill development with achievement of vision and mission of start-up

Participants: In total, 121 start-ups registered with the Government of Karnataka, India, took part in the study. The respondents were from four different cities, namely, Bangalore, Belagavi, Hubli and Dharwad. Researchers contacted 251 start-ups with frequent follow-ups through emails and telecommunication. The survey's respondents included in the study were start-ups with over five years of registration. The final sample size for the study was 121 start-ups. The profile of the respondents is presented in Table 2.

Instrument development: The construct was sufficiently covered in the scale to address research study (Churchill,1979). The study developed the survey instrument based on previous literature. Therefore, the items and scale for vision and mission, strategic objectives, responsibility and accountability, employee engagement and skill development were different. Yet, they were interrelated to the study. Participants of the study were the founders of startups in Karnataka, India. The responses were measured on the five-point Likert scales with an interval ranging from "strongly agree" to "strongly disagree." The questionnaire was presented to respondents in English and Kannada language. The scale was subjected to content validity to enhance the accuracy of data collection. Expert suggestion was collected for clarity concerning strategic management, employee engagement and skill development. The pre-testing process on content validity includes academicians, first-generation entrepreneurs, start-ups founders and university incubators. In all, eight experts guided the researchers in the selection of relevant variables of the construct. The researchers received 


\begin{tabular}{|c|c|c|c|c|c|}
\hline \multirow[b]{3}{*}{ Gender } & \multicolumn{2}{|c|}{ Male } & \multicolumn{2}{|c|}{ Female } & Role of \\
\hline & $N$ & $(\%)$ & $N$ & $(\%)$ & strategic \\
\hline & 106 & 88 & 15 & 12 & management \\
\hline \multicolumn{6}{|l|}{ Age } \\
\hline 21-25 Years & 35 & 33 & 5 & 33 & \multirow{7}{*}{85} \\
\hline 25-30 Years & 29 & 27 & 3 & 20 & \\
\hline 30-35 Years & 16 & 15 & 1 & 7 & \\
\hline $35-40$ Years & 11 & 10 & 3 & 20 & \\
\hline 40-45 Years & 4 & 4 & 1 & 7 & \\
\hline $45-50$ Years & 8 & 8 & 1 & 7 & \\
\hline 50 Years and Above & 3 & 3 & 1 & 7 & \\
\hline \multicolumn{6}{|c|}{ Educational qualification } \\
\hline Engineering & 35 & 33 & 4 & 27 & \\
\hline Commerce & 47 & 44 & 7 & 47 & \\
\hline Science & 9 & 8 & 2 & 13 & \\
\hline Arts & 8 & 8 & 1 & 7 & \\
\hline Management & 7 & 7 & 1 & 7 & \\
\hline \multicolumn{6}{|l|}{ Year of establishment } \\
\hline $2005-2010$ & $\begin{array}{l}10 \\
22\end{array}$ & $\begin{array}{l}10 \\
18\end{array}$ & & & Table 2. \\
\hline $2010-2015$ & 44 & 36 & & & Profile of th \\
\hline 2015-2018 & 39 & 32 & & & respondents \\
\hline
\end{tabular}

feedback on the amending two constructs, namely, Organization Development in Skill Development and Realistic Targets in Strategic Objectives. The experts mentioned that strategic management is a vital component for start-up's development and for the growth of workforce in start-ups. Hence, this research would give new directions to develop effective strategies by involving human resource practices in the study of start-ups. The details with regard to scale development in presented in Table 3.

Data collection: Researchers collected the data from 121 founders of the start-ups in Karnataka, India, through an online survey. We conducted a pilot study on 30 randomly selected start-ups to test reliability of the scale. Cronbach's alpha was used to understand the reliability of the scale. The reliability score of over 0.65 (Henseler et al., 2009) is considered as benchmark for acceptability of the item. Hence, scale items with score over 0.65 were accepted in the study. The data was collected from January 9, 10 and 11, 2018 followed by January 20 and 21, 2020. The total response was $48.0 \%$ with 12 incomplete data responses. We considered finally 121 respondents for the study. Reliability analysis is presented in Table 4.

Measurement model: The reliability analysis of scale measurement proved accuracy of the data collection scale. The preliminary analysis was conducted to check data normality, missing values and multi-collinearity of data. Further, regression analysis was conducted by using SPSS 23. Regression analysis was applied to understand the relationship between the vision and mission statements on strategic objectives; strategic objectives relationship on accountability and responsibility of employees in a startup; accountability and responsibility and its relationship on employee engagement programs in start-ups; role of employee engagement on skill development of employees in start-ups and relationship between skill development of startup employees in achieving vision and mission of startup. Structural equation modeling was administered to understand the relationship among the 


\begin{tabular}{lll}
\hline Construct & Measurement items & Source \\
\hline Vision and Mission & $\begin{array}{l}\text { VM-1-Vision and mission statement are } \\
\text { vital for gaining competitive advantage for }\end{array}$ & Rey and Bastons (2018)
\end{tabular}

start-ups

VM -2 Startups future growth is reflected

Mas-Machuca et al. (2017)

in vision and mission statement of the

startups

VM -3 Vision and mission statement have

a strong impact on employees and

motivates the employees of startups

Strategic objectives

$\mathrm{SO}$ - Performance measurement of startups need to be aligned with strategic objectives of startups.

Accountability and

AR - Acceptance of accountability and responsibility

responsibility towards work task in a startups

Employee

Table 3.

engagement

$\mathrm{EE}$ - Employee engagement is critical for

enhancing the performance of startups

employees

SD - Skill development and its impact on employee performance

Stewart et al. (2017);

Baird (2017)

Brees and Martinko (2015)

Anitha (2014)

Skill development

for the study

\begin{tabular}{llccc}
\hline Construct & Items & Acceptable Score & Cronbach's alpha & Outcome \\
\hline Vision and Mission statement & VM -1 & $>=0.65$ & 0.803 & Supported \\
& VM-2 & $>=0.65$ & 0.775 & Supported \\
& VM -3 & $>=0.65$ & 0.814 & Supported \\
Strategic objectives & SO & $>=0.65$ & 0.793 & Supported \\
Accountability and responsibility & AR & $>=0.65$ & 0.783 & Supported \\
Employee engagement & EE & $>=0.65$ & 0.795 & Supported \\
Skill development & SD & $>=0.65$ & 0.831 & Supported \\
\hline
\end{tabular}

variables of the study. AMOS 23 software was applied to the study. Further, structural equation modeling was applied to test the model and understand the relationship between the variables of the construct. and understand model fit, researchers included following estimates in the analysis $\chi^{2}$ statistic, the goodness of fit index (GFI), root mean square error of approximation (RMSEA), comparative fit index (CFI) and normed fit index (NFI). The summary of an acceptable range of results for the structural equation model is given in Table 5.

\section{Results}

The study tested the model to investigate the proposed relationship between strategic management for employee engagement and skill development in start-ups at Karnataka, India. The psychometric test results of the study presented in Table 6 shows factor loadings between 0.739 to 0.896 (fulfilling factor loadings acceptance range of 0.60 and above). The results on Cronbach's alpha are in an acceptable range of 0.60 and above (study outcomes have shown a result from 0.775 to 0.831 ). They indicate the composite reliability at 0.919 which satisfies the acceptance value of 0.70 and above. Result on average variance extracted 
(AVE) is indicated at 0.874 which satisfies the acceptance value of 0.50 and above. Table 7 shows model summary, Table 8 shows ANOVA analysis and Table 9 shows coefficients analysis of regression analysis used in the study.

The study result shows that "Vision and Mission" statement of start-ups has relationship with "Strategic Objectives" [Regression analysis shows significance level of $(0.000<0.05)$ with Beta coefficient $=0.607$ (indicating positive relationship) and $\left.R^{2}=0.393\right]$. The study result shows that "Strategic Objectives" has relationship with "Responsibility and Accountability" [Regression analysis shows significance level of $(0.000<0.05)$ with Beta coefficient $=0.153$ (indicating positive relationship) and $\left.R^{2}=0.378\right]$. The study result shows that the relationship of "Responsibility and Accountability" with "Employee Engagement" is insignificant [Regression analysis shows significance level of $(0.067>0.05)]$. The study result shows that "Employee Engagement" has relationship with "Skills-development" of employees [Regression analysis shows significance level of $(0.000<0.05)$ with Beta coefficient $=0.328$ (indicating positive relationship) and $\left.R^{2}=0.394\right]$. Finally, the study result shows that the relationship of "Skills-development" with "Vision and Mission" statement is insignificant [Regression analysis shows significance level of $(0.075>0.05)$ ]. All the above results were tested at $5 \%(0.05)$ level of significance.

The proposed model of the study was subjected to structural equation modeling, and results of model fit are presented in Table 10. The model fit analysis showed $\chi^{2}$ of 4.211, $\mathrm{P}<=0.05 . d f=5, \chi^{2} / d f=0.8422, \mathrm{RMSEA}=0.910(>=0.9), \mathrm{CFI}=0.935(>=0.9), \mathrm{NFI}=0.935$ $(>=0.9)$ and GFI $=0.973(>=0.9)$. The results on model fit showed superior fit, as the study results have matched above the standard results for model fitment.

\begin{tabular}{lllll}
\hline Sr. No & Parameters & Acceptable range & Source & \\
\cline { 1 - 2 } 1 & Factor loadings & $>=0.50$ & Bagozzi and Yi (1988) & \\
2 & Composite reliability (C.R) & $>=0.70$ & Fornell and Larcker (1981) & \\
3 & Average variance extracted (AVE) & $>=0.50$ & Chin and Todd (1995) & Table 5. \\
4 & Comparative fit index (CFI) & $>=0.9$ & Chin and Todd (1995) & Acceptable range for \\
5 & Normed fit index (NFI). & $>=0.9$ & Chin and Todd (1995) & results on structural \\
6 & Goodness of fit index & $>=0.9$ & Chin and Todd (1995) & equation modelling \\
7 & Root mean square error of approximation (RMSEA) & $<=0.05$ & Browne et al. (1992) & \\
\hline
\end{tabular}

\begin{tabular}{llcccr}
\hline Construct & Items & Factor loadings & Cronbach's $\alpha$ & Composite reliability & AVE \\
\hline Vision and Mission statement & VM-1 & 0.858 & 0.803 & 0.919 & 0.874 \\
& VM-2 & 0.784 & 0.775 & & \\
Strategic objectives & VM-3 & 0.806 & 0.814 & \\
Accountability and responsibility & SO & 0.896 & 0.793 & \\
Employee engagement & EE & 0.839 & 0.783 & \\
Skill development & SD & 0.566 & 0.795 & \\
\end{tabular}

Notes: $\mathrm{VM}=$ Vison and Mission, $\mathrm{SO}=$ Strategic objectives, $\mathrm{AR}=$ Accountability and responsibility, $\mathrm{EE}=$ Employee engagement, SD = Skill development

Table 6.

Psychometric results of the study 
$\mathrm{XJM}$

$17,1 / 2$

88
Model

Model Summary
Adjusted $R^{2} \quad$ Std. error of the estimate

Strategic objectives are dependent on vision and mission statement

a. Predictors: (strategic objective) b. Dependent

Variable: (Vision and Mission Statement)

0.627

0.393

0.364

0.61785

Accountability and Responsibility are

dependent on strategic objectives

a. Predictors: (Accountability and

Responsibility) b. Dependent Variable: (Strategic

objectives)

$\begin{array}{lll}0.615 & 0.378 & 0.015\end{array}$

0.82735

Accountability and Responsibility are

dependent on employee engagement

a. Predictors: (Accountability and

Responsibility) b. Dependent Variable:

(Employee Engagement)

$0.627 \quad 0.393$

0.733

0.53217

Employee engagement are dependent on skill

development

a. Predictors: (Employee Engagement) b.

Dependent Variable: (Skill Development)

$\begin{array}{lll}0.628 & 0.394 & 0.100\end{array}$

0.96422

Table 7.

Model summary Regression analysis
Skill development is dependent on vision and mission statement

a. Predictors: (Skill Development) b. Dependent

Variable: (Vision and Mission Statement) $\begin{array}{lll}0.629 & 0.396 \quad 0.018\end{array}$

\section{Discussions}

The literature on strategic management for employee engagement and skill development emphasizes on the key role of strategic management on employee engagement and skill development for enhancing growth of start-ups. The primary aim of study was to examine the impact of strategic management on employee engagement and skill development of employees in start-ups. The study developed a model to understand this relationship. This study provides evidence that vision and mission statement of start-ups have a significant relationship with strategic aims. The study findings support earlier studies (Kohtamäki, 2012; Stewart et al., 2017; Alegre et al., 2018) which show that vision and mission statement are critical for the growth of startup and give directions to achieve strategic aims to reach market growth and financial stability. Further, strategic aims have shown significant relationship with development of responsibility and accountability among the employees of startup, these study findings are well supported by the previous studies (Grossman and Burke-Smalley, 2018; Davila et al., 2010; Kohtamäki, 2012). This indicates well defined responsibility and accountability based on strategic objectives of the firm, providing directions to employees on job role clarity and enhancing productivity of employees on the job (Picken, 2017; Carraro et al., 2020). Earlier studies have indicated that accountability and responsibility support in developing effective employee engagement programs in the organizations (Oliveira et al., 2019; Weiblen and Chesbrough, 2015). However, the findings in the study have shown non-congruence with these findings, reason being that start-ups work in a dynamic work environment, wherein challenges are significantly different from traditional organizations; hence, these factors influence in creating effective employee engagement programs for employees. Employee skill development are essential for effective 


\begin{tabular}{|c|c|c|c|c|c|c|}
\hline Model & $\begin{array}{l}\text { ANOVA } \\
\text { Sum of squares }\end{array}$ & df & Mean square & $F$ & Sig. & $\begin{array}{r}\text { Role of } \\
\text { strategic }\end{array}$ \\
\hline $\begin{array}{l}\text { Strategic objectives are dependent on vision and } \\
\text { mission statement } \\
\text { Regression } \\
\text { Residual } \\
\text { Total } \\
\text { a. Predictors: (strategic objective) b. Dependent } \\
\text { Variable: (Vision and Mission Statement) }\end{array}$ & $\begin{array}{l}26.554 \\
45.427 \\
71.981\end{array}$ & $\begin{array}{r}1 \\
119 \\
120\end{array}$ & $\begin{array}{r}26.554 \\
0.382\end{array}$ & 69.559 & $0.000^{\mathrm{b}}$ & 89 \\
\hline $\begin{array}{l}\text { Accountability and Responsibility are dependent } \\
\text { on strategic objectives } \\
\text { Regression } \\
\text { Residual } \\
\text { Total } \\
\text { a. Predictors: (Accountability and Responsibility) } \\
\text { b. Dependent Variable: (strategic objectives) }\end{array}$ & $\begin{array}{r}1.948 \\
81.456 \\
83.404\end{array}$ & $\begin{array}{r}1 \\
119 \\
120\end{array}$ & $\begin{array}{l}1.948 \\
0.685\end{array}$ & 2.846 & $0.000^{\mathrm{b}}$ & \\
\hline $\begin{array}{l}\text { Accountability and Responsibility are dependent } \\
\text { on employee engagement } \\
\text { Regression } \\
\text { Residual } \\
\text { Total } \\
\text { a. Predictors: (Accountability and Responsibility) } \\
\text { b. Dependent Variable: (Employee Engagement) }\end{array}$ & $\begin{array}{r}93.588 \\
33.702 \\
127.290\end{array}$ & $\begin{array}{r}1 \\
119 \\
120\end{array}$ & $\begin{array}{r}93.588 \\
0.283\end{array}$ & 330.455 & $0.012^{\mathrm{b}}$ & \\
\hline $\begin{array}{l}\text { Employee engagement are dependent on skill } \\
\text { development } \\
\text { Regression } \\
\text { Residual } \\
\text { Total } \\
\text { a. Predictors: (Employee Engagement) } b . \\
\text { Dependent Variable: (Skill Development) }\end{array}$ & $\begin{array}{r}13.381 \\
110.637 \\
124.017\end{array}$ & $\begin{array}{r}1 \\
119 \\
120\end{array}$ & $\begin{array}{r}13.381 \\
0.930\end{array}$ & 14.392 & $0.000^{\mathrm{b}}$ & \\
\hline $\begin{array}{l}\text { Skill development is dependent on vision and } \\
\text { mission statement } \\
\text { Regression } \\
\text { Residual } \\
\text { Total } \\
\text { a. Predictors: (Skill Development) b. Dependent } \\
\text { Variable: (Vision and Mission Statement) }\end{array}$ & $\begin{array}{r}2.478 \\
91.202 \\
93.681\end{array}$ & $\begin{array}{r}1 \\
119 \\
120\end{array}$ & $\begin{array}{l}2.478 \\
0.766\end{array}$ & 3.234 & $0.075^{\mathrm{b}}$ & $\begin{array}{r}\text { Table } 8 . \\
\text { ANOVA - } \\
\text { Regression analysis }\end{array}$ \\
\hline
\end{tabular}

employee engagement programme; however, the study showed skill development programs in start-ups are effective, but owing to dynamic work environment accountability and responsibility and skill development do not correlate with effective engagement programmes. These findings are in congruence with earlier studies on employee engagement, accountability and responsibility and skill development (Manning,2016; Gulyani and Sharma, 2018). Therefore, skill development program in start-ups needs to be addressed and matched with vision and mission of startup. This will enhance productivity of the start-up; these findings of skill gap paucity were addressed in earlier research findings (Picken, 2017; Kuschel et al., 2018;; Patel and Mehta, 2016; Majumdar et al., 2020).

The above discussions show that, start-ups need to build on effective skill development programs for employees to achieve vision of the startup and also device effective tools with clear role clarity to support employees on accountability and responsibility on the job. 
XJM

$17,1 / 2$

90

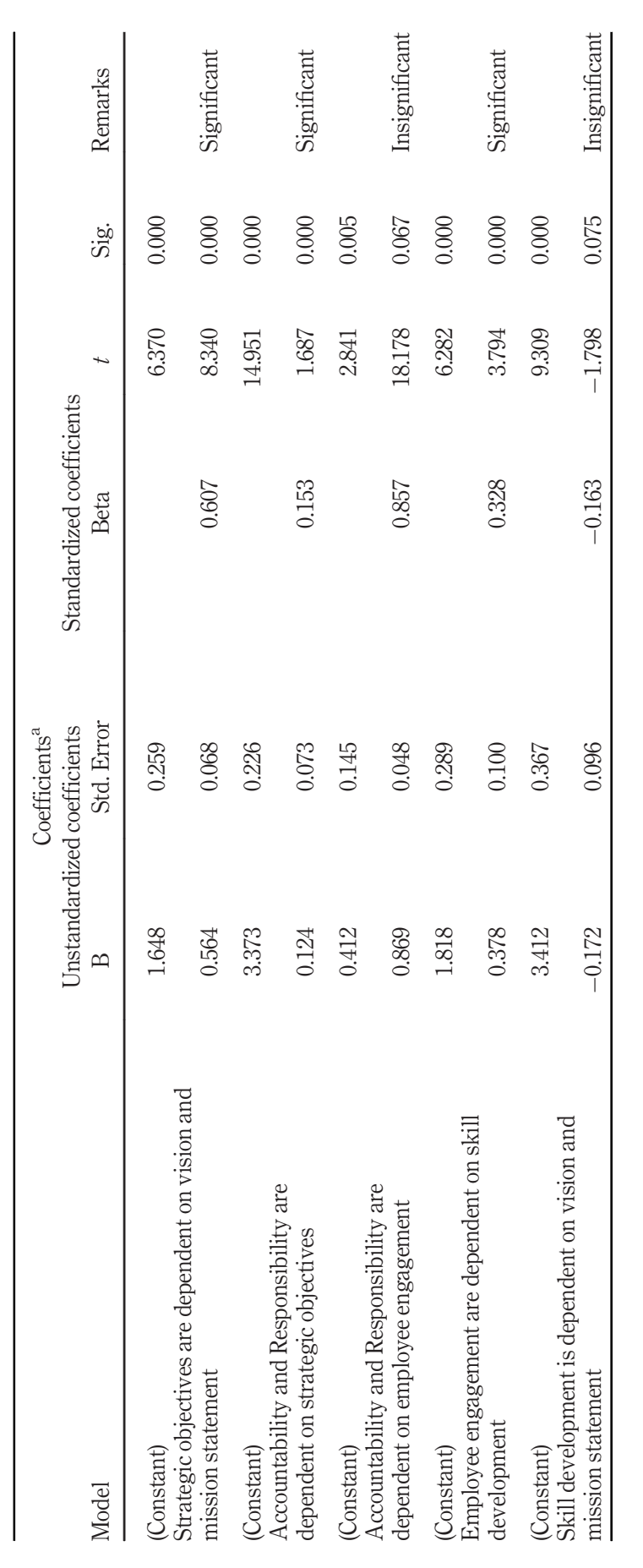

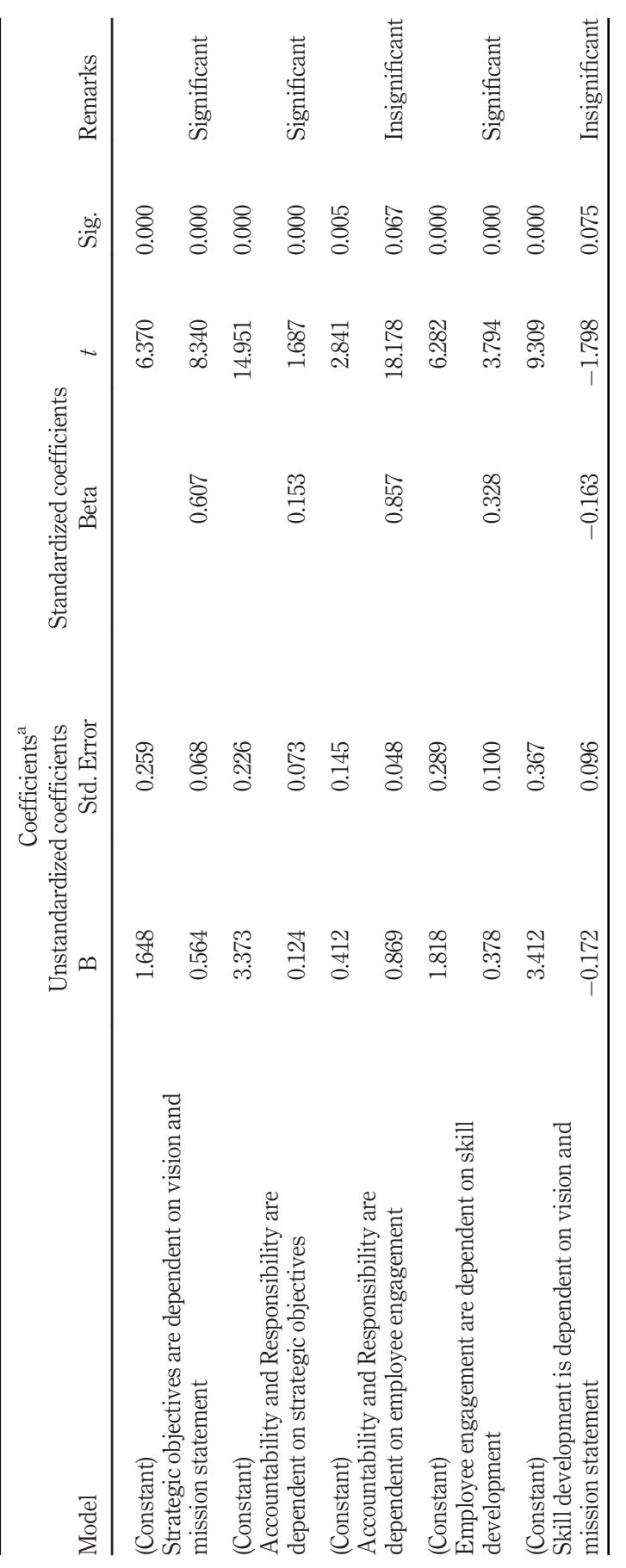

Table 9.

Coefficients analysis - Regression analysis 


\section{Practical implications}

The findings of study have significant managerial implications that may support the startups with a better understanding of strategic management from the employee's perspective.

Study on the impact of skill gap amongst the employee is reflected on vision and mission of start-ups. Therefore, it is important for the startup's founders to create awareness among the employees on vision and mission statement and how skill sets are important for effectively achieving vision of the start-ups. Training programs support in developing skill sets for employees. Effective methods of training need identification to close skill gap will support in higher level of performance among the employees. This should act in bridging the gap in skill shortage among the employees.

Another key study area emerged in the study from the perspective of employee engagement programs in start-ups. Founders and practitioners need to test the right tools for employee engagement, as these tools give directions to employees to understand the responsibility and accountability.

However, the study findings indicated that employee engagement programs are effective but not been effective in developing skill set of the employees and achieving vision and mission of start-ups, probably because most of the start-ups have focused on market growth and financial growth; hence, in the vision and mission of start-up, employee's perspective needs to be considered. This might support in developing role clarity, better engagement programs and achievement of the same.

\section{Conclusion}

Start-ups provide an opportunity for the growth of an economy. The present study provided directions on strategic management from the perspective of employees in a startup. The study results show that start-ups need to develop clarity in vision and mission statement from the perspective of skill development. Results show that start-ups need to develop techniques and tools for employee engagement and skill development in line with employee's expectations. The overall results of the study showed start-ups strategic management practices are effective. However, from the perspective of human resource management, skill development is a critical factor for the growth of start-ups.

The present study was confined to start-ups in Karnataka, India. However, studies on specific areas of start-ups such as the technology-driven start-ups, health care-related startups can provide further research directions for the study. Additionally, managerial arearelated studies including financial management of start-ups, operational management and marketing management can provide in-depth information for the growth of a start-up community in India.

\begin{tabular}{lcc}
\hline $\begin{array}{l}\text { Model Fit } \\
\text { Variables }\end{array}$ & Standard & Results \\
\hline$\chi^{2}$ (chi-square) & - & 4.211 \\
$d f($ Degree of Freedom) & - & 5 \\
$\chi^{2} /$ df & - & 0.8422 \\
Comparative fit index (CFI) & $>=0.9$ & 0.966 \\
Normed fit index (NFI). & $>=0.9$ & 0.935 \\
Goodness of fit index & $>=0.9$ & 0.973 \\
Root mean square error of approximation (RMSEA) & $<=0.5$ & 0.310 \\
\hline
\end{tabular}

\section{Role of strategic management}

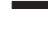


$\mathrm{XJM}$

$17,1 / 2$

\section{References}

Afolayan, A., Plant, E., White, G.R., Jones, P. and Beynon-Davies, P. (2015), "Information technology usage in SMEs in a developing economy", Strategic Change, Vol. 24 No. 5, pp. 483-498.

Agrawal, N., Banda, M., Marshall, A., Mehrotra, N. and Patrao, C. (2017), "How India can be essential to the global ecosystem economy", Strategy and Leadership, Vol. 45 No. 4, pp. 33-39.

Alegre, I., Berbegal-Mirabent, J., Guerrero, A. and Mas-Machuca, M. (2018), "The real mission of the mission statement: a systematic review of the literature", Journal of Management and Organization, Vol. 24 No. 4, pp. 456-473.

Allio, R.J. (2006), "Strategic thinking: the ten big ideas", Strategy and Leadership, Vol. 34 No. 4, pp. 4-13.

Anitha, J. (2014), "Determinants of employee engagement and their impact on employee performance", International Journal of Productivity and Performance Management, Vol. 63 No. 3, pp. 308-323.

Bagozzi, R.P. and Yi, Y. (1988), "On the evaluation of structural equation models", Journal of the Academy of Marketing Science, Vol. 16 No. 1, pp. 74-94.

Baird, K. (2017), "The effectiveness of strategic performance measurement systems", International Journal of Productivity and Performance Management, Vol. 66 No. 1, pp. 3-21.

Baptista, R., Karaöz, M. and Mendonça, J. (2014), "The impact of human Capital on the early success of necessity versus opportunity-based entrepreneurs", Small Business Economics, Vol. 42 No. 4, pp. 831-847.

Barringer, B.R., Jones, F.F. and Neubaum, D.O. (2005), "A quantitative content analysis of the characteristics of rapid-growth firms and their founders", Journal of Business Venturing, Vol. 20 No. 5, pp. 663-687.

Bendickson, J.S., Muldoon, J., Liguori, E.W. and Midgett, C. (2017), "High performance work systems: a necessity for startups", Journal of Small Business Strategy, Vol. 27 No. 2, pp. 1-12. No

Bicho, M., Nikolaeva, R. and Lages, C. (2019), "Social enterprise legitimacy in a hostile market", Developments in Marketing Science: Proceedings of the Academy of Marketing Science, Springer International Publishing, pp. 153-165.

Biga Diambeidou, M. and Gailly, B. (2011), "A taxonomy of the early growth of Belgian start-ups", Journal of Small Business and Enterprise Development, Vol. 18 No. 2, pp. 194-218.

Boxall, P., Hutchison, A. and Wassenaar, B. (2014), "How do high-involvement work processes influence employee outcomes? An examination of the mediating roles of skill utilisation and intrinsic motivation", The International Journal of Human Resource Management, Informa UK Limited, Vol. 26 No. 13, pp. 1737-1752.

Bratianu, C. (2017), "Strategic thinking in turbulent times", Proceedings of the International Conference on Business Excellence, Vol. 11 No. 1, pp. 248-254.

Brees, J. and Martinko, M.J. (2015), "Judgments of responsibility versus accountability", Journal of Leadership and Organizational Studies, SAGE Publications, Vol. 22 No. 4, pp. 443-453.

Carraro, W.B.W.H., Battisti, S. and Brito, C. (2020), "Identifying innovative practices of management control among start-ups", International Journal of Management Practice, Vol. 13 No. 4, p. 401.

Cascio, W.F. and Graham, B.Z. (2016), "New strategic role for HR: leading the employer-branding process", Organization Management Journal, Vol. 13 No. 4, pp. 182-192.

Chin, W.W. and Todd, P.A. (1995), "On the use, usefulness, and ease of use of structural equation modeling in MIS research: a note of caution”, MIS Quarterly, Vol. 19 No. 2, pp. 237-246.

Churchill, G.A. Jr (1979), “A paradigm for developing better measures of marketing constructs”, Journal of Marketing Research, Vol. 16 No. 1, pp. 64-73.

Coad, A., Nielsen, K. and Timmermans, B. (2016), "My first employee: an empirical investigation", Small Business Economics, Vol. 48 No. 1, pp. 25-45.

Cornock, M. (2011), "Legal definitions of responsibility, accountability and liability", Nursing Children and Young People, Vol. 23 No. 3, pp. 25-26. 
Davila, A., Foster, G. and Jia, N. (2010), "Building sustainable high-growth startup companies: management systems as an accelerator", California Management Review, Vol. 52 No. 3, pp. 79-105.

Dixit, U. (2018), "Strategic role of human resource management in employee skill development: an employer's perspective", the social ION", Diva Enterprises Private Limited, Vol. 7 No. 2, pp. 85-92.

Felce, A., Perks, S. and Roberts, D. (2016), "Work-based skills development: a context-engaged approach”, Higher Education, Skills and Work-Based Learning, Vol. 6 No. 3, pp. 261-276.

Fornell, C. and Larcker, D.F. (1981), "Evaluating structural equation models with unobservable variables and measurement error", Journal of Marketing Research, Vol. 18 No. 1, pp. 39-50.

Forster, M., Parrer, P. and Wöss, N.M. (2013), "Personality: blessing or curse? The entrepreneur's path from personal to leadership competencies”, Organizacija, Vol. 46 No. 5, pp. 221-231.

Giardino, C., Bajwa, S.S., Wang, X. and Abrahamsson, P. (2015), "Key challenges in early-stage software startups", Lecture Notes in Business Information Processing, Springer International Publishing, pp. 52-63.

Girotra, R. and Kaushik, T. (2018), "Talent acquisition challenges faced by Indian e-commerce startups: culture as a moderator", IUP Journal of Entrepreneurship Development, Vol. 15 No. 2, pp. 24-43.

Grossman, R. and Burke-Smalley, L.A. (2018), “Context-dependent accountability strategies to improve the transfer of training: a proposed theoretical model and research propositions", Human Resource Management Review, Vol. 28 No. 2, pp. 234-247.

Gulyani, G. and Sharma, T. (2018), "Total rewards components and work happiness in new ventures: the mediating role of work engagement", Evidence-Based Hrm: a Global Forum for Empirical Scholarship, Vol. 6 No. 3, pp. 255-271.

Hasan, I., Kobeissi, N., Wang, H. and Zhou, M. (2017), "Bank financing, institutions and regional entrepreneurial activities: evidence from China”, International Review of Economics and Finance, Vol. 52, pp. 257-267.

Henseler, J., Ringle, C.M., and Sinkovics, R.R. (2009), "The use of partial least squares path modeling in international marketing", in Sinkovics, R.R. and Ghauri, P.N. (Eds), New Challenges to International Marketing (Advances in International Marketing, Vol. 20), Emerald Group Publishing Limited, Bingley, pp. 277-319.

Jiang, H. and Luo, Y. (2018), “Crafting employee trust: from authenticity, transparency to engagement", Journal of Communication Management, Vol. 22 No. 2, pp. 138-160.

Jones, P., Beynon, M.J., Pickernell, D. and Packham, G. (2013), "Evaluating the impact of different training methods on SME business performance", Environment and Planning C: Government and Policy, Vol. 31 No. 1, pp. 56-81. No

Kaur, G. and Sharma, R.R.K. (2019), "Total reward strategies to attract and retain employees: an analysis of Indian startups", Journal of Management Research, Vol. 19 No. 4, pp. 221-234.

Kohler, T. (2016), "Corporate accelerators: Building bridges between corporations and startups", Business Horizons, Vol. 59 No. 3, pp. 347-357.

Kohtamäki, M., Kraus, S., Mäkelä, M. and Rönkkö, M. (2012), "The role of personnel commitment to strategy implementation and organisational learning within the relationship between strategic planning and company performance", International Journal of Entrepreneurial Behavior and Research, Vol. 18 No. 2, pp. 159-178.

Kuschel, K., Labra, J.P. and Díaz, G. (2018), "Women-led startups and their contribution to job creation", FGF Studies in Small Business and Entrepreneurship, Springer International Publishing, pp. 139-156.

Lee, J.Y., Rocco, T.S. and Shuck, B. (2019), "What is a resource: toward a taxonomy of resources for employee engagement”, Human Resource Development Review, Vol. 19 No. 1, pp. 5-38. 
$\mathrm{XJM}$

$17,1 / 2$

Majumdar, S.K., Sarma, A.P. and Majumdar, S. (2020), "E-commerce and digital connectivity: unleashing the potential for greater India-ASEAN integration", Journal of Asian Economic Integration, Vol. 2 No. 1, pp. 62-81.

Manning, A. (2016), "Unlocking the power of employee happiness: what top employees seek from the workplace today", Strategic HR Review, Vol. 15 No. 4, pp. 191-192.

Mas-Machuca, M., Ballesteros-Sola, M. and Guerrero, A. (2017), "Unveiling the mission statements in social enterprises: a comparative content analysis of US- vs Spanish-based organizations", Journal of Social Entrepreneurship, Vol. 8 No. 2, pp. 186-200.

Mintzberg, H. (1994), "The fall and rise of strategic planning”, Harvard Business Review, Vol. 72 No. 1, pp. 107-114.

Moquin, R., K. Riemenschneider, C. and L. Wakefield, R. (2019), "Psychological contract and turnover intention in the information technology profession”, Information Systems Management, Vol. 36 No. 2, pp. 111-125.

Moser, K.J., Tumasjan, A. and Welpe, I.M. (2017), "Small but attractive: dimensions of new venture employer attractiveness and the moderating role of applicants' entrepreneurial behaviors", Journal of Business Venturing, Vol. 32 No. 5, pp. 588-610.

Naldi, L. and Picard, R.G. (2012), "Let's start an online news site': Opportunities, resources, strategy, and formational myopia in startups", Journal of Media Business Studies, Vol. 9 No. 4, pp. 69-97.

Newbery, R., Lean, J., Moizer, J. and Haddoud, M. (2018), "Entrepreneurial identity formation during the initial entrepreneurial experience: the influence of simulation feedback and existing identity", Journal of Business Research, Vol. 85, pp. 51-59.

Oliveira, A., Moro, S. and Torres, P. (2019), "Psychological contract, internal branding and employee turnover in an IT company", Academic Journal of Interdisciplinary Studies, Vol. 8 No. 1, pp. 9-18.

Patel, S. and Mehta, K. (2016), "Systems, design, and entrepreneurial thinking: comparative frameworks", Systemic Practice and Action Research, Vol. 30 No. 5, pp. 515-533.

Picken, J.C. (2017), "From startup to scalable enterprise: Laying the foundation", Business Horizons, Vol. 60 No. 5 , pp. 587-595.

Rabideau, M.M., Wong, K., Gordon, E.S. and Ryan, L. (2016), “Genetic counselors in startup companies: redefining the genetic counselor role”, Journal of Genetic Counseling, Vol. 25 No. 4, pp. 649-657.

Rey, C. and Bastons, M. (2018), "Three dimensions of effective mission implementation", Long Range Planning, Vol. 51 No. 4, pp. 580-585.

Salamzadeh, A. and Kawamorita Kesim, H. (2017), "The enterprising communities and startup ecosystem in Iran", Journal of Enterprising Communities: People and Places in the Global Economy, Vol. 11 No. 4, pp. 456-479.

Sasaki, I., Kotlar, J., Ravasi, D. and Vaara, E. (2020), "Dealing with revered past: historical identity statements and strategic change in Japanese family firms", Strategic Management Journal, Vol. 41 No. 3, pp. 590-623.

Stewart, D., Gibson-Smith, K., MacLure, K., Mair, A., Alonso, A., Codina, C., Cittadini, A., FernandezLlimos, F., Fleming, G., Gennimata, D. and Gillespie, U. (2017), "A modified delphi study to determine the level of consensus across the European union on the structures, processes and desired outcomes of the management of polypharmacy in older people”, Plos One, Vol. 12 No. 11, p. e0188348.

Talaulicar, T., Grundei, J. and Werder, A.V. (2005), "Strategic decision making in start-ups: the effect of top management team organization and processes on speed and comprehensiveness", Journal of Business Venturing, Vol. 20 No. 4, pp. 519-541.

Tunstall, R., Jordain, C., Pittaway, L. and Thomas, B. (2009), "Achieving strategic intent through corporate venturing", The International Journal of Entrepreneurship and Innovation, Vol. 10 No. 4, pp. 301-312. 
Waddock, S.A., Bodwell, C. and Graves, S.B. (2002), "Responsibility: the new business imperative", Academy of Management Perspectives, Vol. 16 No. 2, pp. 132-148.

Watson, K., Hogarth-Scott, S. and Wilson, N. (1998), "Small business start-ups: success factors and support implications", International Journal of Entrepreneurial Behavior and Research, Vol. 4 No. 3, pp. 217-238.

Weiblen, T. and Chesbrough, H.W. (2015), "Engaging with startups to enhance corporate innovation", California Management Review, Vol. 57 No. 2, pp. 66-90.

White, G.R.T., Jones, P. and Beynon-Davies, P. (2015), "The strategic impact of information technology deployment", Strategic Change", , Vol. 24 No. 5, pp. 401-403.

Yadav, N. and Sehgal, V. (2019), "India's super 50 companies and their mission statement: a multifold perspective", Journal of Strategy and Management, Vol. 12 No. 2, pp. 208-226.

Zaheer, H., Breyer, Y., Dumay, J. and Enjeti, M. (2019), "Straight from the horse's mouth: founders' perspectives on achieving 'traction 'in digital start' ups", Computers in Human Behavior, Vol. 95, pp. 262-274.

Zahra, S.A. and Nambisan, S. (2012), "Entrepreneurship and strategic thinking in business ecosystems", Business Horizons, Vol. 55 No. 3, pp. 219-229.

\section{Further reading}

Berger, E.S. and Kuckertz, A. (2016), "Raising the level of female entrepreneurship in startup ecosystems", Academy of Management Proceedings, Vol. 2016 No. 1, pp. 13844.

Browne, M.W. and Cudeck, R. (1992), "Alternative ways of assessing model fit”, Sociological Methods and Research, SAGE Publications, Vol. 21 No. 2, pp. 230-258.

Edison, H. (2015), "A conceptual framework of lean startup enabled internal corporate venture", Product-Focused Software Process Improvement, Springer International Publishing, pp. 607-613.

Ferrell, O.C. and Ferrell, L. (2011), "The responsibility and accountability of CEOs: the last interview with Ken Lay", Journal of Business Ethics, Springer Science and Business Media LLC, Vol. 100 No. 2, pp. 209-219, available at: https://doi.org/10.1007/s10551-010-0675-y

Frederiksen, D.L. and Brem, A. (2016), "How do entrepreneurs think they create value? A scientific reflection of Eric Ries' lean startup approach", International Entrepreneurship and Management Journal, Springer Science and Business Media LLC, Vol. 13 No. 1, pp. 169-189.

Georgallis, P. and Durand, R. (2017), "Achieving high growth in policy-dependent industries: differences between startups and corporate-backed ventures", Long Range Planning, Vol. 50 No. 4, pp. 487-500.

Klotins, E., Unterkalmsteiner, M. and Gorschek, T. (2018), "Software engineering in start-up companies: an analysis of 88 experience reports, empirical software engineering", Empirical Software Engineering, Vol. 24 No. 1, pp. 68-102.

Yu, B., Hao, S., Ahlstrom, D., Si, S. and Liang, D. (2013), "Entrepreneurial firms' network competence, technological capability, and new product development performance", Asia Pacific Journal of Management, Springer Science and Business Media LLC, Vol. 31 No. 3, pp. 687-704.

\section{Corresponding author}

Praveen Kulkarni can be contacted at: pmkulkarni@git.edu

For instructions on how to order reprints of this article, please visit our website:

www.emeraldgrouppublishing.com/licensing/reprints.htm

Or contact us for further details: permissions@emeraldinsight.com 